University of Nebraska - Lincoln

DigitalCommons@University of Nebraska - Lincoln

Marketing Department Faculty Publications

Marketing Department (CBA)

2006

Service Personalization and Loyalty

A. Dwayne Ball

University of Nebraska - Lincoln, dball1@unl.edu

Pedro S. Coelho

New University of Lisbon, Psc@isegi.unl.pt

Manuel J. Vilares

New University of Lisbon, mjv@isegi.unl.pt

Follow this and additional works at: https://digitalcommons.unl.edu/marketingfacpub

Part of the Marketing Commons

Ball, A. Dwayne; Coelho, Pedro S.; and Vilares, Manuel J., "Service Personalization and Loyalty" (2006). Marketing Department Faculty Publications. 13.

https://digitalcommons.unl.edu/marketingfacpub/13

This Article is brought to you for free and open access by the Marketing Department (CBA) at DigitalCommons@University of Nebraska - Lincoln. It has been accepted for inclusion in Marketing Department Faculty Publications by an authorized administrator of DigitalCommons@University of Nebraska - Lincoln. 


\section{Service Personalization and Loyalty}

\section{Dwayne Ball, Pedro S. Coelho, Manuel J. Vilares}

Contact information:

Dr. A. Dwayne Ball

Associate Professor of Marketing

University of Nebraska

324 CBA 0492

Lincoln, Nebraska 68588 USA

Office: 402-472-2381

e-mail: dball1@unl.edu

Dr. Pedro S. Coelho

Associate Professor

ISEGI

New University of Lisbon

Campus de Campolide

1070-312 Lisbon

Portugal

e-mail: psc@isegi.unl.pt

Dr. Manuel J. Vilares

Professor

ISEGI

New University of Lisbon

Campus de Campolide

1070-312 Lisbon

Portugal

e-mail: mjv@isegi.unl.pt 


\title{
Service Personalization and Loyalty
}

\begin{abstract}
Purpose: To investigate the effect of service personalization on loyalty, and to measure some of the psychological dynamics of the process.

Methodology: structural equation modeling.

Findings: We show that the effect of service personalization on loyalty exists, but that the effect is not all direct. Personalization works through improving service satisfaction and trust. Personalization and improved communication act together in such a way that they account for the variance in loyalty that would be otherwise explained by corporate image.

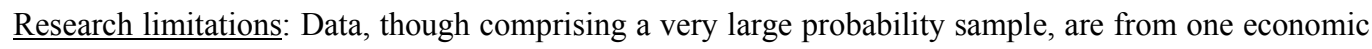
sector in one European country.

Practical implications: Service personalization is a powerful way to retain customers in its own right. In addition, our other results show that personalized service can partially replace the effects of communication and corporate image on loyalty. This argues that personalized service can be a powerful addition to mass communications.

Originality/value: Growing conventional wisdom in marketing argues that customer loyalty is responsible for large fractions of the profits of many service businesses. Constructs such as satisfaction, trust, customer collaboration, customer interaction, firm image, personalization, learning relationships, and so forth, have all been proposed as intermediate objectives, or as tools to build loyalty. Yet, to date, only some of these constructs have been measured and shown to be related to loyalty. This paper fills a portion of the empirical gap by showing that service personalization, indeed, affects loyalty, above and beyond the other explanatory variables.
\end{abstract}

$\underline{\text { Key words: }}$ customer loyalty, customer equity, personalization, satisfaction

Categorization: Research paper 


\section{INTRODUCTION}

Consumers have relationships with service providers, and these relationships can be simple and straightforward, or complex and emotional (e.g., Peppers and Rogers 2004). This paper explores the effect of personalizing service on the relationship. In particular, we ask, "What is the effect of service personalization on loyalty?"

For our purposes here, we will define "service personalization" as any creation or adjustment of a service to fit the individual requirements of a customer. This can be as simple as a fast-food restaurant allowing a customer to "hold the mayonnaise," to a textbook publisher allowing a university professor to create a custom textbook from disparate sources, to a bank constructing a large custom loan package for an important customer. It includes the notion of entirely individualized services, as well as "masscustomized" (Gilmore and Pine, 2000) services.

We argue that service personalization improves loyalty through several routes. First, properly-done personalization of a service should obviously improve customer satisfaction, which is a primary antecedent of loyalty. Services that fit the customer's needs better should naturally be more satisfactory than one-size-fits-all. In addition, we will argue, personalized services may encourage the customer to believe that the firm is benevolent towards him or her, increasing trust, which is an antecedent of loyalty. After all, one explanation for the extra effort involved in personalization is the attribution of benevolent motives to the firm. Finally, we will argue for a direct effect of personalization on loyalty, arising from sources such as the tendency of consumers to view personalized services as difficult to replace with another provider. Hence, service personalization should normally improve loyalty. 


\section{Loyalty and its causes}

Marketers have been urged for nearly two decades (Dwyer, et al. 1987) to shift their thinking away from isolated transactions, and instead to pay close attention to the creation and nurturance of these relationships, and particularly to the development of loyalty in customers (e.g., Reichheld 1996). The loyalty referred to here is not behavioral loyalty (repurchase or re-patronization), but rather, emotional loyalty: the desire on the part of the customer to continue the relationship even if competitors lower prices, willingness to recommend to friends, and intention to continue to patronize (Dick and Basu, 1994; Zeithaml, 2000; Chaudhuri and Holbrook, 2001). This construct, sometimes called "customer equity" (Rust et al. 2000), is the customer's affective and conative end-state that should lead to repurchase or repatronization, willingness to expand purchasing beyond the initially-purchased line of services or products, indifference to competitor's appeals, lower price-sensitivity, positive word-of-mouth, and other serendipitous effects on a customer's individual lifetime profitability and the overall profitability of the firm.

In this paper, we use as our base model of loyalty the European Customer Satisfaction Index (ECSI) model as reported by Ball, Coelho, and Machás (2004), which was originally closely derived from the American Customer Satisfaction Index model (Fornell et al. 1996; Johnson, et al., 2001). In this updated ECSI model (see Figure 1), our "base" model for this paper, loyalty is explained by the customer's satisfaction with service, the firm's image as a stable and responsible service provider, the satisfactory or unsatisfactory nature of the firm's complaint-handling, communication between the firm and the customer, and the customer's trust of the service provider. 
Other constructs in the model (expectations, perceived value, and perceived quality) are used to explain satisfaction, not loyalty, and need not concern us here. Figure 2 shows the path coefficients solved in the most recent evolution of the model, which was created using data from a study of the Portuguese banking industry identical to the one reported in this paper, except for the constructs added in this paper. The original ECSI model (which does not have trust or communication as our base model does) is well-established as a tool for measuring and explaining customer satisfaction and its antecedents and related constructs (Gronholdt et al., 2000; Cassel and Eklof, 2001; Vilares and Coelho, 2004). It has been validated across a number of European countries and many industries, such as insurance, mobile phones, fixed phones, carbonated soft drinks, public transportation, retail banking, cable TV, supermarkets, postal services, food products, and public service.

To our base model, which explains loyalty with satisfaction, trust, communication, and complaint-handling (and image, indirectly), we will add personalization. Our purpose is to determine if, and how, personalization might add explanatory power. In other words, given that we already have a good, validated model of satisfaction and loyalty, what does personalized service add? First, we will discuss each of the current explanations for loyalty, and then personalization, to determine if it can explain loyalty above and beyond the others.

\section{$\underline{\text { Take in Figure } 1}$}

Customer Satisfaction. The effects of customer satisfaction on loyalty have been well-conceptualized and well-researched (e.g. Oliver 1999). Customer satisfaction 
can be thought of as a basis for loyalty, but hardly the whole story. Satisfied customers frequently switch, but there is something else that keeps satisfied customers coming back instead of switching away when competitors advertise, promote, offer discounts, and so forth. There is something else that keeps customers coming back even when there is an occasional service failure.

Trust. The effects of trust, a central variable in relationships, have also been wellconceptualized and well-researched (e.g. Moorman et al., 1993; Morgan and Hunt, 1994; Lim, Razzaque and Abdur 1997; Garbarino and Johnson 1999; Chaudhuri and Holbrook 2001). Trust can be thought of as having two components, performance or credibility trust and benevolence trust (Ganesan 1994), with credibility trust (belief that the provider will deliver on promises) as clearly critical in both consumer market and business-to-business contexts. Singh and Sirdeshmurk (2000) and Singh et al. (2002) argue that benevolence trust (the belief that the service provider is acting the best interests of the customer and will not take advantage of the relationship), at least in consumer markets, may be critical as well. In this paper, which deals with consumer markets, we define trust as primarily benevolence trust.

Communication, properly-done, causes trust, as might be obvious from observation of human relationships, and as also proposed by Morgan and Hunt (1994) in business relationships. Communication can be personalized letters, direct mail, website interactions, other machine-mediated interactions, and e-mail, or in-person communication with service personnel before, during, and after service transactions. Positive communication from the service provider is helpful, positive, timely, useful, easy, and pleasant; it leaves the customer feeling not only satisfied with the service, 
but with a positive affect towards the provider. The effect of good communication in a B2C relationship is to increase overall service satisfaction, the customer's trust of the service provider, and loyalty (Ball et al., 2004).

Image. Company reputation, or image, affects trust (Anderson and Weitz, 1989); this was found to be true the base model test (Ball, et al. 2004, see Figure 2). Our operational construct of company image includes items measuring customer perceptions of the firm's stability, social contributions to society, concern with customers, reliability of what the firm says and does, and innovativeness. The base model also shows, as expected, a direct effect of image on satisfaction (but not on loyalty). In other words, the more positive the corporate image, the greater the satisfaction with the firm's service, and the greater the trust of the firm. Since trust and satisfaction affect loyalty, there is an indirect effect of image on loyalty.

Complaint handling. Poorly-handled complaints may well lead to customer attributions of opportunistic behaviour on the part of the firm (complaint-handling was proposed by Morgan and Hunt, 1994, as an antecedent of trust), or may be interpreted as simply base incompetence, which would have a negative effect on credibility and performance trust (Ganesan, 1994). Complaint handling is validated as an antecedent of loyalty in the ECSI model and also as an antecedent of trust (Ball, et al., 2004).

\section{$\underline{\text { Take in Figure } 2}$}




\section{Personalization}

The growth of interest in one-to-one marketing over the past 10 years (Peppers and Rogers, 1993) has brought the topic of personalization of products, services, and communications to an increasingly prominent position in marketing theory and practice. However, measurement and estimation of the effects of personalization on other critical theory constructs has been lacking (Day and Montgomery 1999, p. 8).

Personalization has always been a feature of products and services when marketers have had the resources to use personalization for competitive advantage. General Motors superseded Ford Motor as the US's largest automobile manufacturer seventy years ago, according to marketing lore, because Ford produced cars in one color only, and GM offered the customer more color options. Today, automobile manufacturers offer the customer a wide variety of options for many features on each model, making autos "mass-customized." Some formerly mass-produced products are now mass customized, and more such personalized products can be expected in the future (Gilmore and Pine, 2000). Landsend.com and JCPenny.com are among the clothing retailers that allow the customer to design clothing that is a much better fit for his or her size, body characteristics, and tastes than off-the-rack clothing.

Many product categories, such as furniture, tools, firearms, books, kitchen implements, toys, and so forth that were once highly individualized craft articles are now almost entirely mass-produced, but may be largely personalized once again in the future (except made unique by machine rather than by hand). We may someday even

come to say that the era of mass-produced products in the late $19^{\text {th }}$ and entire $20^{\text {th }}$ centuries was an aberration in marketing history. The vast increases in computing 
power, manufacturing robotics, and the rise of the Internet over recent decades have now given marketers the power to customize offerings to ever more demanding customers, in ways they could not before.

In contrast to products, however, nearly all services have been in some sense personalized since their inception, offering the customer a wide variety of options, from legal services (entirely personalized), to higher educational services (partially personalized), to fast food (slightly personalized). Some services, such as hair dressing for women, are so highly personalized as to form a significant part of the customer's life satisfaction (Price and Arnould, 1999). In fact, any part of the marketing mix can be personalized. Not only can the product or service be personalized, but so can the form of distribution, the pricing, or the promotion. Amazon.com, for example, like a number of websites (Ansari et al., 2000; Ansari and Mela 2003), more effectively promotes its merchandise through personalized recommendations for products based on collaborative filtering technology. So, personalization is clearly a phenomenon worthy of attention.

\section{The ECSI model of Satisfaction and Loyalty}

The ECSI model as derived and solved on the Portuguese banking sector in 2002 is presented in Figure 2 (Ball, et al. 2004). The dependent constructs of greatest interest are customer satisfaction and loyalty. The explanatory constructs are corporate image, expectations, service quality, perceived value, complaint-handling, trust, and communication.

\section{INTRODUCING PERSONALIZATION INTO MODELS OF LOYALTY}




\section{Effects of Personalized Service}

Personalization has largely been assumed to affect satisfaction and loyalty (e.g. Peppers and Rogers 1993; Rust et al. 2000), but formal hypothesis tests of these connections are lacking, and we provide some here. The rationale makes common sense: personalization should produce a more satisfactory transaction, and over time, a more satisfactory relationship. Personalized service should simply be better service than routine service that does not take the individual's needs into account. Naturally, it is possible to make personalized service worse than routine unpersonalized service, but it is against the interests of the firm to expend resources on personalization without doing it well enough to reap benefits of increased customer satisfaction.

$\mathrm{H}_{1 \mathrm{a}}$ : Personalization will be positively related to satisfaction in the presence of other explanatory constructs.

Personalization should also have an impact on trust. The "trust" of interest here is benevolence trust, which is the belief that the service provider will not take advantage of the relationship to enrich himself at the customer's expense, and will deliver what is required by the customer, not just what is convenient for the firm. Trust is a critical variable in explaining loyalty in many business contexts, but may have only a weak relationship to loyalty in others. We expect some direct relationship between personalization and trust, and will model it as a causal path from personalization to trust.

The rationale for this is that personalized service may serve as a signal to the consumer that the service provider is interested enough in the welfare of the customer to customize his services. Customers do, on occasion, attribute qualities such as 
kindness and benevolence to firms (Williams and Murphy 1990). An example would be a stockbrokerage house carefully considering the goals of the investor before recommending stock and bond trades. The customer could make an attribution that the brokerage was expending extra effort on him or her purely due to competitive pressure - which is a stable and external attribution that would increase performance trust. Or, the customer could make an attribution that the brokerage was driven by benevolent concern for the customer's welfare, as many financial service providers advertise themselves to be. If the customer makes such a stable, internal attribution to the service provider, that would increase benevolence trust. A stable, internal attribution of benevolence is clearly in the firm's interests to promote, and many firms train employees to have a caring attitude toward customers and to exhibit signs of such an attitude. Whether the customer believes that the firm's concern for the customer is internally-driven or externally-driven, the attribution that the firm is driven to provide a higher level of service is nonetheless stable, and should lead to trusting the provider. Clearly, the matter of exactly how personalization may act on trust is more complex than we can explore here empirically, but we can at least confirm that the linkage exists.

$$
\begin{aligned}
& \mathrm{H}_{1 \mathrm{~b}} \text { : Personalization will be positively related to trust in the presence of other } \\
& \text { explanatory constructs. }
\end{aligned}
$$

Finally, a direct path from personalization to loyalty may exist because personalization often involves learning about the customer's preferences on the part of the service provider; for the customer to switch away would mean training another service provider, i.e., incurring set-up costs (Burnham, et al., 2003). Therefore, a kind of "retention equity" (Rust, et al., 2000) is created which leads to emotional loyalty. 
$\mathrm{H}_{1 \mathrm{c}}$ : Personalization will be positively related to loyalty in the presence of other explanatory constructs.

\section{Causing the Perception of Personalization}

Personalization of service largely requires three things: 1. a service provider willing and able to adjust his or her offerings to the individual customer, 2. a customer who desires something different from other customers, and 3. communication between the customer and the service provider to establish the parameters of personalization what the customer uniquely needs, and what the service provider can do, uniquely, for that customer. When a company communicates well with the customer, the customer's sense that he or she is being personally addressed and cared for should rise. Accordingly, in the base model displayed in Figure 1, we use the existing measure of level of communication and build a path from it to personalization. That many customers desire unique products and services (Tian, et al., 2001), or would find them more satisfactory, is probable, but not yet measured in our model. The willingness of the service provider to provide personalized service is also not measured, since this model is based in consumer perceptions rather than objective measures of the service.

$\mathrm{H}_{2}$ : Communication will be a positively-related antecedent of personalization

\section{Summary of causes and effects of personalization}

In adding personalization to our base model we have four new paths above and beyond those validated in the literature. First, communication causes personalization. This path indicates that communication can act directly on trust, as in Figure 1, but may also have an indirect effect on trust through personalization. Second, 
personalization causes satisfaction. Third, personalization causes trust, and fourth, personalization causes loyalty. Either the percentage of variance explained in trust, loyalty, and satisfaction will increase over the percentages explained in Figure 2 because of the addition of these four new paths, or the coefficients on established paths in Figure 2 will change to accommodate the new explanatory construct, personalization. Figure 3 shows the revised model.

\section{$\underline{\text { Take in Figure } 3}$}

\section{APPLICATION TO THE BANKING INDUSTRY}

\section{Data}

Data come from a survey of banking customers corresponding to the 2002 wave of the Portuguese Customer Satisfaction Index (ECSI - Portugal). ECSI-Portugal is a national customer satisfaction study, producing yearly results regarding several industries (including the retail banking). The selection of the respondents follows the criteria defined in ECSI (1998) ${ }^{[1]}$. The questionnaire used in the survey queries the overall experience of the respondent with the bank, and is based on the one adopted in the ECSI-Portugal project. The questionnaire includes a set of questions regarding the nine constructs of the base model (image, expectations, perceived quality, perceived value, complaints, communication, trust, customer satisfaction and customer loyalty), plus a set of questions regarding the new personalization construct. The indicators used in the measurement model for the constructs communication, trust and image are presented in Table $\mathrm{I}^{[2]}$. The sample size is 2500 observations, corresponding to 250 interviews for each studied bank. The study includes 9 individual banking companies 
plus a residual group of "other banks," representing small banks. The 9 bank brands represent a total market share of almost $70 \%$.

\section{Estimation}

The complete model, which includes the structural model and the measurement model, is formally presented in appendix 1 . The structural model is composed of ten latent variables, as shown in Figure 3. The measurement model relates latent variables to the manifest variables.

\section{Take in Table I}

Partial Least Squares (PLS) was used to estimate the base model and the revised model. This option is mainly motivated by the nature of the data. In fact we are measuring categorical variables with an unknown non-normal frequency distribution, which is usually negatively skewed. In this context PLS can be a preferable alternative to the use of maximum likelihood methods (comparisons between maximum likelihood methods and partial least squares can be found in Dijkstra, 1983 and Chin, 1998). Also PLS has been the standard estimation method in the context of ECSI-Portugal and in American Customer Satisfaction Index (ACSI). The estimation is done separately for each of the 10 studied banks/brands. This resulted in the estimation of 20 models. The two models are also estimated based on the whole data set of banking industry. 


\section{RESULTS}

Table II shows model explanatory power (through determination coefficient, $R^{2}$ ) of the equations explaining customer satisfaction, loyalty and trust, both in the base and the revised model. For the latter model the $R^{2}$ for personalization is also shown. From the results presented in Table II it can be seen that the revised model shows a higher explanatory power for customer satisfaction, loyalty and trust, when compared with the base model. The average determination coefficient for satisfaction is $73.4 \%$ in the revised model, which represents an increase of 1.9 percentage points when compared to the base model. When considering the individual brands, the $R^{2}$ for satisfaction, in the revised model, increases between -0.1 and 5.9 percentage points. The minimum of $R^{2}$ for satisfaction in the base model is $67.2 \%$ and for the revised model is $71.1 \%$; the maximum value is $75.3 \%$ and $77.8 \%$ for both models, respectively.

For loyalty, $R^{2}$ is increased by -0.2 to 3.3 percentage points. The minimum $R^{2}$ is $50.4 \%$ in the base model and $50.8 \%$ in the revised model. The maximum $R^{2}$ are $71.4 \%$ and $72.7 \%$ for each model, respectively. For the revised model, the average $R^{2}$ for loyalty is $64.8 \%$, representing an increase of 1.3 percentage points when compared to the base model.

In the revised model trust presents a determination coefficient of $71.0 \%$ (more 2.2 . points than for the base model). The results obtained for the ten banks show that the $R^{2}$ for trust increases between -0.3 and 5.3 percentage points when compared to the base model. The minimum of $R^{2}$ for trust in the base model is $59.3 \%$ and for the revised model is $64.6 \%$; the maximum value is $73.8 \%$ and $75.4 \%$ for both models, respectively. 
The $R^{2}$ values for personalization are generally lower than the ones observed for satisfaction and loyalty (54.4\% on average), which is easily understandable since in our model personalization is exclusively explained by communication. Nevertheless, results clearly confirm that communication is a non-negligible contributing construct for creating the perception of personalization.

Globally, results show that, for the banking sector, in addition to the antecedents already considered in the base model, personalization still adds some explanatory power to customer satisfaction, loyalty and trust ${ }^{[3]}$. These increases tend to be more significant for satisfaction and trust than for loyalty. Note also that banks obtaining the lowest $R^{2}$ for satisfaction, loyalty and trust in the base model tend to show more significant increases in the explanatory capability. One interesting result is that the revised model tends to have a lower variability in the explanatory capability among different banks.

The explanatory power of personalization is also confirmed by the effect sizes ${ }^{[4]}$ for evaluating the predictive importance of each determinant of customer satisfaction, loyalty and trust (see Table III). It can be easily observed that personalization always shows significant effect sizes for prediction of those three constructs. In fact, it is consistently the second highest effect size, with only image being larger when explaining satisfaction, only satisfaction being larger when explaining loyalty, and only communication being larger when explaining trust.

\section{Take in Table II}




\section{$\underline{\text { Take in Table III }}$}

Table IV shows Cronbach Alphas, communalities $\left(H^{2}\right)$ and redundancy coefficients $\left(F^{2}\right)$ for the new variable personalization included in the revised model, by bank $^{[5]}$.These measures can be used as indicators of the validity and predictive relevance of the model (Nunally, 1978; Lohmöler, 1989). In all cases latent variable communalities are significantly higher than .70 , indicating that the variance captured by each latent variable is significantly larger than variance due to measurement error, and thus demonstrating a high convergent validity of the construct. The alpha coefficients confirm this conclusion showing values always higher than .79. The redundancy coefficients also tend to confirm the quality of the model. The average alpha coefficient for personalization is .819 , the average communality is .736 and the average redundancy coefficient is .400 .

\section{$\underline{\text { Take in Table IV }}$}

Discriminant validity is accessed determining if: (1) each latent variable shares more variance with its own measurement variables than with other constructs, and (2) each measurement variable is more correlated with its own latent variable than with other constructs (Chin, 1998). For that, we have compared measurement variables' communalities with the squared correlations between their own construct and other constructs in the model. A low percentage of latent variable squared correlations exceeding measurement variables communalities tend to confirm discriminant validity. Also we have compared the correlations of measurements variables with 
their own latent variables and with all the other constructs in the model. If discriminant validity exists we should expect to find a low percentage of correlations with other constructs exceeding the correlation with the directly connected latent variable (Table V). In fact, regarding the first criterion there are no violations for personalization, thus confirming a strong validity of the construct. Also for the second criteria only one violation was found. It regards the observed variable "My bank offers me products and services that satisfy my specific needs, " that for one of the ten banks was more correlated with the communication construct than with personalization. So, results regarding this criterion still confirm the validity of the personalization construct.

\section{$\underline{\text { Take in Table } V}$}

Figures 2 and 4 present the estimates and $t$ values for path coefficients for the base and revised models. Dashed lines represent non-significant impacts at a 5\% significance level.

Regarding the estimation of path coefficients involving the new construct personalization, it can be concluded that:

- In our model personalization is only explained by communication. The effect of communication on personalization is significant and high (4.2), thus confirming $\mathrm{H}_{2}$. In fact, this is the most significant effect originating with communication. The effect of communication on trust is also impressive (2.4), but smaller. The effects 
of communication on loyalty and on satisfaction are lower, but of the same magnitude (1.1 on satisfaction and 0.8 on loyalty).

- Personalization has three direct effects, all significant, on satisfaction, loyalty and trust. The most significant effect of personalization is on trust (1.2 for the banking sector). The effects of personalization on loyalty and on satisfaction are also significant and of the same magnitude (1.0). Thus, hypotheses $\mathrm{H}_{1 \mathrm{a}}, \mathrm{H}_{1 \mathrm{~b}}$, and $\mathrm{H}_{1 \mathrm{c}}$ are confirmed.

In the base model loyalty is directly explained by image, communication, satisfaction and complaints. The revised model adds personalization. This causes a decrease in the estimated effects from communication, satisfaction and trust on loyalty. The impacts of image (non-significant) and complaints remain almost unchanged and satisfaction continues to be the construct with the highest direct effect on loyalty in the revised model. Communication, personalization and trust appear to have similar effects on customer loyalty $(0.8,1.0$ and 0.8 respectively) that were higher than the effects of image or complaints.

Satisfaction is directly explained by image, expectations, perceived quality, perceived value, communication and personalization. With the exception of expectations all the predicted constructs showed significant effects on satisfaction. The introduction of personalization causes a decrease in the estimated effects of communication, image and perceived value on satisfaction. Among these, the most significant decrease was observed from communication. The impacts from expectations and perceived quality remained almost unchanged. Communication, image, perceived quality and the new construct personalization seem to have similar effects on customer loyalty $(1.1,1.3$, 
1.3 and 1.0 respectively) that are significantly higher than the ones originating in expectations or perceived value.

Trust is directly explained by image, communication and personalization. All the determinants showed significant impacts on trust. The introduction of personalization causes important decreases in the estimated effects of image and communication. Communication continues to be the construct with the highest direct effect on trust in the revised model (2.4). Personalization presents a significantly smaller effect (1.2), but higher than the one originated by image $(0.8)$.

\section{$\underline{\text { Take in Figure } 4}$}

Tables VI and VII show the total model effects (direct plus indirect effects) for each model (origins of the effects in rows and destinations in columns).

While in the base model satisfaction showed the most important total effect on customer loyalty, in the revised model results show that satisfaction is no longer the most important variable for explaining loyalty. The total effect of satisfaction on loyalty is (for revised model), 2.6; lower than the effect of communication (3.2). The new variable personalization also shows an important effect on loyalty (1.7). All the other variables already included in the base model show significantly lower effects. Among these, perceived quality and trust are the ones that present the most important

total effect on customer loyalty in the revised model $(0.8)$. With the exception of communication, all the constructs included in the base model seem to lose importance in explaining customer loyalty. Image and customer satisfaction are the ones whose 
total effects showed a more pronounced reduction. On the other hand, expectations and complaints are the ones that almost weren't affected by the introduction of personalization. These results seem to show that in the base model the lack of consideration of personalization tended to overestimate the importance of other dimensions as image, satisfaction, perceived quality and trust in the explanation of loyalty. In particular, due to the significant decrease of the image effect, one might conclude that part of the effect of personalization on loyalty could be mistakenly attributed to corporate image. Also, the effect of communication seemed to be underestimated as a result of not accounting for its indirect effects operating through personalization.

Image has the highest total impact on customer satisfaction (2.0) in the base model, followed by perceived quality and communication. In the revised model, the variables showing the most important effects on satisfaction are communication (1.9), perceived quality (1.6) and personalization (1.0). While the total effects of expectations and perceived quality are not affected by the introduction of personalization, this is not the case for perceived value and image, which seem to lose importance. This is particularly notable for image, whose effect on customer satisfaction show a very important decrease between the base model and revised model. Image, in the base model, seemed to be the most important determinant of satisfaction, while in the new model it appears as the determinant with the least significant effect. Once again, these results seem to show that in the base model the lack of consideration of personalization tended to overestimate the importance of image, and in some degree of perceived value in the explanation of satisfaction. As noted for explaining customer loyalty, the effect of communication on satisfaction 
seemed to be underestimated as a result of not accounting for its indirect effects operating through personalization.

Finally, when approaching the explanation of trust, it can be seen that communication shows the highest total effect in both models. In the base model the second most important variable seemed to be image, but in the revised model this is surpassed by the effect of personalization. In fact, only the effects from image and communication show significant differences between the two models. Once again, this change has opposite signals. The base model seems to overestimate the effect of image and underestimate the effect of communication on trust.

\section{$\underline{\text { Take in Table VI }}$}

\section{$\underline{\text { Take in Table VII }}$}

\section{DISCUSSION}

\section{Theoretical effects of personalization}

First, it is apparent that the addition of personalization adds power in terms of explaining satisfaction, loyalty, and trust, the most critical variables for a marketer. In addition, some of the existing relationships explaining satisfaction, loyalty, and trust are reduced in strength, indicating that personalization is taking some explanatory power away from existing constructs. In fact, although the increase in the determination coefficients offered by personalization are somewhat modest, this 
construct always shows important effect sizes, confirming a high relevance of this predictor. In particular, it is apparent that communication acts on trust, loyalty, and satisfaction partially through personalization, and that it is therefore less strongly related to those constructs directly. Nevertheless, it is worth noting that the total effect of communication on satisfaction and trust was underestimated in the base model, as a result of not accounting its indirect effects operated through personalization. Second, it is apparent that image is the variable whose effects on satisfaction, loyalty and trust are most affected by the addition of personalization. We can therefore conclude that it is somewhat less strongly related to these constructs as it was suggested in the base model. Finally, trust is less strongly related to loyalty, while personalization is explanatory of both.

The theoretical significance of these effects, in total, is two-fold. First, personalization of services is an important antecedent of loyalty, satisfaction, and trust. These effects have long been assumed, but now have some empirical backing. Second, image matters less than previously estimated. A personal or personalized relationship evidenced by a measurable level of personalization - compensates for a decline in a clear, strong brand image. In effect, “If we know each other personally, I don't care as much what other people say about you."

Personalization increases satisfaction and benevolence trust, which also have their effects on loyalty. A personalized relationship, built on communication, is more trusting and more satisfactory - in short, a "closer" relationship, and more likely to endure. Personalization adds psychological comfort to relationships and increases the psychological barriers to switching. Personalization increases benevolence trust, 
which is built up over time; switching service providers therefore becomes a risk. Furthermore, personalization increases satisfaction, and switching providers may now involve an increased risk of lower satisfaction. So, for all these psychological dynamics, personalization of services is a substantial cause of loyalty.

Finally, the effect of the reduction of the trust-loyalty linkage due to adding personalization is a small conundrum. We suspect this may be an effect confined to sectors like banking, which are highly government-regulated. All providers are trustworthy, at least at the middle-class consumer level. Loyalty may therefore be much less a matter of trust, and much more a matter of satisfaction, personalization, image, and communication, as the model in Figure 4 indicates. A useful rubric in this case is that provided by Rust, et al. (2000), which categorizes the causes of loyalty into value equity (customer satisfaction), brand equity (largely brand image and communication), and retention equity (unwillingness to lose unique privileges or enjoyments, often such as those provided by personalization). Trust itself may be, in such regulated industries, a result of communication and image; but in their presence and the presence of personalization, trust may not add any explanatory power to loyalty.

\section{Managerial implications}

First, personalization enhances satisfaction, trust, and loyalty, and is therefore valuable in its own right.

- Service personalization programs should be tested and then (if successful) implemented, where service personalization is feasible and customer loyalty is likely to improve sales above and beyond the costs of personalization. 
- Satisfaction, trust, emotional loyalty, and customer profitability should be measured through observational and survey methods to assess the effects of service personalization programs.

Second, service personalization may change the allocation of resources designed to enhance corporate image, customer satisfaction, trust, and loyalty among existing customers. Our empirical results show that the effects of personalization replace the various effects of communication and image on satisfaction, trust, and loyalty. Resources devoted to delivering the core service may not change, but resources devoted to communications might be re-allocated. With service personalization, the relationship between the firm and customer should become "closer" by virtue of the firm's appropriate use of knowledge about the customer, and the customer's increasing trust and emotional loyalty. Less standardized advertising should therefore be necessary to those customers.

- Some of the advertising resources devoted to maintaining brand awareness and image among current customers may be switched to personalization efforts, as personalization appears to substitute for some of the effects of those communications (this would have to be tested in each context).

Our work here has shown that personalizing services has a definite effect on loyalty. The effect is complex, but it argues that an emerging model of customer relationships, one-to-one marketing, in which personalizing services is key, can explain and enhance loyalty.

\section{Limitations}


This work has the usual limitations of a study confined to a single market sector in a single industrialized Western country. That is, such banking markets differ from some other markets in being highly regulated and in offering a fairly standard array of services that are, in many respects, easily compared across providers as to price and terms of service, with low switching barriers. Therefore, the place of personalization in the competitive mix may be greater or lesser than in other markets, and the effect of personalization on loyalty may be more or less. The market for mobile telephone services, for example, may be less easy to compare across providers because of complex service contracts, and have strong structural barriers to switching because of switching penalties. In that case, personalization may be less and loyalty may depend less upon it.

Other limitations are those common to structural equation modeling in cross-sectional designs. Effects are modeled as linear, but may not be in fact. It might well be that there are diminishing returns to increasing personalization, but these cannot be reflected by a single parameter. Further, it is clear that customer relationships build over time. Each relationship is a series of transactions, and each transaction leaves its mark on the relationship. Cross-sectional research cannot fully capture the dynamic, interactive, and non-linear nature of so many relationship variables.

\section{Future research}

This research has confirmed that personalization is important and that it is related in multiple ways to loyalty. More research to create a more refined conceptualization of personalization is needed. What is personalized service for each different type of service? How do relationships develop over time as a service provide attempts to 
adapt its offerings to an individual customer? What inferences does the customer make regarding the service provider after one successful personalization attempt? After two, three, and four? How can personalization attempts fail? These are all important questions that will need to be addressed as information technology facilitates even more service personalization.

\section{APPENDIX 1. MODEL EQUATIONS}

The general form of the structural model of ECSI revised model is:

$$
\begin{gathered}
\eta=\beta \eta+\gamma \xi+v \\
E(v \mid \xi)=\mathbf{0}
\end{gathered}
$$

where $\eta^{\prime}=\left(\eta_{1}, \eta_{2}, \ldots, \eta_{8}\right)$ represents the vector of endogenous latent variables, $\xi^{\prime}=\left(\xi_{1}, \xi_{2}\right)$ the vector of exogenous latent variables, $\beta$ e $\gamma$ the parameter matrices of suitable order and $v$ the error term.

The equations of the model represented in Figure 1 are:

$$
\left[\begin{array}{l}
\eta_{1} \\
\eta_{2} \\
\eta_{3} \\
\eta_{4} \\
\eta_{5} \\
\eta_{6} \\
\eta_{7} \\
\eta_{8}
\end{array}\right]=\left[\begin{array}{cccccccc}
0 & 0 & 0 & 0 & 0 & 0 & 0 & 0 \\
\beta_{21} & 0 & 0 & 0 & 0 & 0 & 0 & 0 \\
\beta_{31} & \beta_{32} & 0 & 0 & 0 & 0 & 0 & 0 \\
0 & 0 & 0 & 0 & 0 & 0 & 0 & 0 \\
0 & 0 & 0 & \beta_{54} & 0 & 0 & \beta_{57} & 0 \\
\beta_{61} & \beta_{62} & \beta_{63} & \beta_{64} & 0 & 0 & 0 & 0 \\
0 & 0 & 0 & 0 & 0 & \beta_{76} & 0 & 0 \\
0 & 0 & 0 & \beta_{74} & \beta_{75} & \beta_{76} & \beta_{77} & 0
\end{array}\right]\left[\begin{array}{c}
\eta_{1} \\
\eta_{2} \\
\eta_{3} \\
\eta_{4} \\
\eta_{5} \\
\eta_{6} \\
\eta_{7} \\
\eta_{7}
\end{array}\right]+\left[\begin{array}{cc}
\gamma_{11} & 0 \\
0 & 0 \\
0 & 0 \\
0 & \gamma_{42} \\
\gamma_{51} & \gamma_{52} \\
\gamma_{61} & \gamma_{62} \\
0 & 0 \\
\gamma_{71} & \gamma_{72}
\end{array}\right]\left[\begin{array}{l}
\xi_{1} \\
\xi_{2}
\end{array}\right]+\left[\begin{array}{c}
v_{1} \\
v_{2} \\
v_{3} \\
v_{4} \\
v_{5} \\
v_{6} \\
v_{7} \\
v_{8}
\end{array}\right](2)
$$

where

$\xi_{1}$ : image; $\xi_{2}:$ communication; $\eta_{1}:$ customer expectations; $\eta_{2}:$ perceived quality of products and services; $\eta_{3}:$ perceived value; $\eta_{4}$ personalization; $\eta_{5}:$ customer trust; $\eta_{6}:$ customer satisfaction (ECSI); $\eta_{7}:$ complaints; $\eta_{8}:$ customer loyalty. 
The measurement model, relating the latent variables to the manifest variables, has the general form:

$$
\begin{gathered}
\mathbf{y}=\Lambda_{y} \eta+\varepsilon \\
\mathbf{x}=\Lambda_{x} \xi+\delta \\
E(\varepsilon)=E(\delta)=E(\varepsilon \mid \eta)=E(\delta \mid \xi)=\mathbf{0}
\end{gathered}
$$

where $\mathbf{y}^{\prime}=\left(y_{1}, y_{2}, \ldots, y_{p}\right)$ and $\mathbf{x}^{\prime}=\left(x_{1}, x_{2}, \ldots, x_{q}\right)$ are the manifest endogenous and exogenous variables, respectively. $\Lambda_{y}$ and $\Lambda_{x}$ are the corresponding parameters matrices.

Representing by $\mathbf{y}_{i}^{\prime}=\left(y_{i 1}, \ldots, y_{i H_{i}}\right)$ the vector of manifest variables related to the latent endogenous variable $\eta_{i}$, and by $\mathbf{x}_{i}^{\prime}=\left(x_{i 1}, \ldots, x_{i G_{i}}\right)$ the vector of manifest variables related to the latent exogenous variable $\xi_{i}$, we can also write the model in the form

$$
\begin{aligned}
& y_{i j}=\lambda_{y i j} \eta_{i}+\varepsilon_{i j}, \quad i=1, \ldots, 8 ; j=1, \ldots, H_{i} \\
& x_{i j}=\lambda_{x i j} \xi_{i}+\delta_{i j}, \quad i=1, \ldots, 2 ; j=1, \ldots, G_{i}
\end{aligned}
$$

where $H_{i}$ is the number of manifest variables associated with variable $\eta_{i}$ and $G_{i}$ is the number of manifest variables associated with variable $\xi_{i}$. 


\section{REFERENCES}

Anderson, E.W; Weitz, B. (1989) "Determinants of Continuity in Conventional Industrial Channel Dyads”, Marketing Science, Vol 8 No 4, pp.310-323.

Alexander, N.; Colgate, M. (2000) "Retail financial services: transaction to relationship marketing", European Journal of Marketing, Vol 34 No 8, pp. 938-953.

Allen, D.; Wilburn, M. (2002), Linking customer and employee satisfaction to the bottom line, ASQ Quality Press.

Anderson, E.W; Fornell, C. (1994), "Customer satisfaction, market share and profitability: findings from Sweden", Journal of Marketing, Vol 58 No 3, pp.53.

Anderson, E.W; Weitz, B. (1989), "Determinants of Continuity in Conventional Industrial Channel Dyads”, Marketing Science, Vol 8 No 4, pp.310-323.

Anderson, E.W; Fornell, C. (2000), "Foundations of the American Customer Satisfaction Index", Total Quality Management, Vol 11 No 7, pp.869-882.

Ansari, Asim, Skander Essegaier, and Rajeev Kohli (2000) "Internet Recommendation Systems." Journal of Marketing Research, Vol 37 No. 3, pp. 363-375.

Ansari, A, and Mela, C. (2003) E-customization. Journal of Marketing Research, Vol. 40 No. 2, pp. 131-145.

Ball, A. D., Coelho, P. S., and Machás, A. (2004). "The Role of Communication and Trust in Explaining Customer Loyalty: an extension to the ECSI Model” European Journal of Marketing, Vol. 38. Available from the authors.

Bennett, R.; Rundle-Thiele (2002), “A comparison of attitudinal loyalty measurement approaches”, Journal of Brand Management, Jan. Vol 9 No 3, pp. 193-209.

Bernstel, J. (2001), “Strained Relationship”, Bank Marketing, Vol 33 No 10, pp. 14-19.

Bolton, R.; Bramlet, M.; Kannan, P. (2000), "Implications of loyalty program membership and service experiences for customer retention and value", Journal of the Academy of Marketing Science, Vol 28 No 1, pp. 95-108.

Bruhn, M.; Grund, M. (2000), “Theory, development and implementation of national customer satisfaction indices: The Swiss Index of Customer Satisfaction (SWICS)", Total Quality Management, Vol 11 No7, pp.1017-1028.

Burnham, Thomas, Judy Frels, and Vijay Mahajan (2003) Consumer Switching Costs: A Typology, Antecedents, and Consequences. Journal of the Academy of Marketing Science, Vol. 31 No. 2, pp. 109-126.

Buttle, F.; Burton, J. (2002), “Does service failure influence customer loyalty?”, Journal of Consumer Behaviour, Feb. Vol 1 No 3, pp.217-227.

Cassel, C.; Eklof, J. A. (2001), "Modelling customer satisfaction and loyalty on aggregate levels: Experience from the ECSI pilot study", Total Quality Management, Vol. 12 No 7-8, pp.834-841.

Chaudhuri, A.; Holbrook, M. (2001), "The chain of effects from brand trust and brand effect to brand performance: the role of brand loyalty", Journal of Marketing, Vol 65 No 2, pp.81-93. 
Chin, W. W. (1998), “The Partial Least Squares Approach to Structural Equation Modeling”, in Marcoulides, G. A. (ed.), Modern Methods for Business Research, cap 10, NJ Lawrence Erlbaum Associates.

Cronin, J.; Brady, M.; Hult, T. (2000), "Assessing the effects of quality, value and customer satisfaction on consumer behavioural intentions in service environments", Journal of Retailing, Vol 76 No 2, pp.193-218.

Crosby, L., Evans, K. and Cowles, D (1990), "Relationship quality in service selling: an interpersonal influence perspective", Journal of Marketing, Vol 54 no 3, pp 66-81

Day, G.. and Montgomery, D. (1999) Charting New Directions for Marketing, Journal of Marketing, Vol. 63 (special issue), pp. 3-13.

De Wulf, K.; Schoroder, G.; Lacobucci, D. (2001), "Investments in consumer relationship: a crosscountry and cross industry exploration”, Journal of Marketing, Vol 65 No 4, pp.33-50.

Dick, A.; Basu, K. (1994), “Customer loyalty: toward an integrated conceptual framework”, Journal of the Academy of Marketing Science, Vol 22 No 2, pp. 99-113.

Dijkstra, T. (1983), "Some Comments on Maximum Likelihood and Partial Least Squares Methods", Journal of Econometrics, 22, pp. 67-90.

Dwyer, R. F., Schurr, P.; Oh, S. (1987), “Developing buyer-seller relationships”, Journal of Marketing, Vol 51 No 2, pp.11-27.

Finnie, W.; Randall, R. (2002), "Loyalty as a philosophy and strategy: an interview with Frederick F.Reichheld”, Strategy and Leadership, Vol 30 No 2, pp.25-31.

Fornell, C. (1992), “A National Customer Satisfaction Barometer: The Swedish Experience”, Journal of Marketing, Vol 56 No 1, pp. 6-21.

Fornell, C; Johnson, M.D.; Anderson, E.W.; Cha, J.; Bryant, B. (1996), “The American Customer Satisfaction Index: nature, purpose and findings", Journal of Marketing, Vol.60 No 4, pp.7-18.

Fournier, S.; Dobscha, S.; Mick, D. (1998), "Preventing the premature death of relationship marketing”, Harvard Business Review, Vol 76 No 1, pp.42-51.

Ganesan, S. (1994), "Determinants of Long-term Orientation in Buyer-Seller Relationships", Journal of Marketing, Vol 58 No 2, pp.1-19.

Ganesh, J.; Reynolds, K.; Arnold, M. (2000), "Understanding the customer base of service providers: an examination of the differences between switchers and stayers", Journal of Marketing, Vol 64 No 3 , pp.65-87.

Garbarino, E.; Johnson, M. (1999), “The different roles of satisfaction, trust and commitment in customer relationships", Journal of Marketing, Vol 63 No 2, pp.70-87.

Gilmore, J.. and Pine, J. (editors) (2000) Markets of One: Creating Customer-Unique Value through Mass Customization, Cambridge, MA: Harvard Business School Press.

Grewal, D.; Parasuraman, A.; Voss, G. (1998), "The roles of price, performance and expectations in determining satisfaction in service exchanges”, Journal of Marketing, Vol.62 No 4, pp.46-61.

Gronholdt, L.; Martensen, A.; Kristensen, K. (2000),. "Customer satisfaction measurement at post Denmark: Results of application of the European Customer Satisfaction Index methodology", Journal of Total Quality Management, Vol 11 No 7, pp.1007-1015. 
Gundlach, G.; Achrol, R.; Mentzer, J. (1995), “The structure of commitment in exchange”, Journal of Marketing, Vol 59 No 1, p.78-92 .

Hallowell, R (1996), “The Relationship of Customer Satisfaction, Customer Loyalty, and Profitability: An Empirical Study”, International Journal of Services Industry Management, Vol 7 No 4, pp.27-42.

Hart, C.; Johnson, M. (1999), “Growing the trust relationship”, Journal of Marketing Management, Vol 8 No 1, pp.8-19.

Jacoby, J. and Chestnut, R. W. (1978), Brand Loyalty: Measurement and Management, Wiley and Sons, New York.

Johnson, M.; Gustafsson, A.; Andreason, T. W.; Lervik, L.; and Cha, G. (2001) "The evolution and future of national customer satisfaction index models", Journal of Economic Psychology, Vol 22 (217245).

Jones, M.; Mothersbaugh, D.; Beatty, S. (2000), "Switching barriers and repurchase intentions in service", Journal of Retailing, Vol 76 No 2, pp.259-274.

Lim, K.; Razzaque, Abdur, M. (1997), "Brand loyalty and situational effects: An interactionist perspective”, Journal of International Consumer Marketing, Vol 9 No 4, pp.95-115.

Kandampully, J. (1998), "Service quality to service loyalty: a relationship witch goes beyond customer services”, Journal of Quality Management, Vol 9 No 6, pp.431-443.

Keaveney, S. (1995), "Customer switching behaviour in service industries: an exploratory study", Journal of Marketing, Vol 59 No 2, pp. 71-82.

Lichtenstein, D., Netemeyer, R, and Burton, S. (1995), “Assessing the domain-specificity of dealproneness: a field study”, Journal of Consumer Research, Vol 22 no 3, pp. 314-326

Lohmöler, J.B. (1989), Latent variable path-modelling with partial least squares, Heidelberg: Physicaverlag.

Morgan, R.; Hunt, S. (1994), “The commitment-trust theory of relationship marketing”, Journal of Marketing, Vol 58 No 3, pp.20.

Morgan, R. (2000), “A consumer-oriented framework of brand equity and loyalty", Marketing Research Society, Vol 42 No 1, pp.65-78.

Moorman, C.; Gerald Z.; Rohit D. (1993), "Factors Affecting Trust in Marketing Relationships", Journal of Marketing, Vol 57 No 1, pp.81-101.

Nunally, J. C. (1978), Psychometric theory, Willey, $2^{\text {nd }}$ ed, New York.

Oliver, R (1997), Satisfaction: A Behavioural Perspective on the Consumer, Irwin/McGraw-Hill, Boston.

Oliver, R. (1998), "New directions in the study of the consumer satisfaction response: anticipated evaluation, intend cognitive-affective process and trust influences on loyalty", Advances in Consumer Research, Vol 25.

Oliver, R. (1999), "Whence Consumer Loyalty?", Journal of Marketing, Vol 63 (special issue), pp. 3344

Oliver, R. T. and Swan, J.E. (1995), "Equity and disconfirmation perceptions as influences on merchant and product satisfaction” Journal of Consumer Research, Vol 16 No 3, pp. 372-383 
Parasuraman, A.; Berry, L.; Zeithaml, V. (1991), "Perceived service quality as a customer based performance measure: An empirical examination of organizational barriers using an extended service quality model", Human Resource Management, Vol 30 No 3, pp.335-365.

Parasuraman, A.; Berry, L.; Zeithaml, V. (1996), “The behavioural consequences of service quality”, Journal of Marketing, Vol 60 No 2, pp.31-47.

Parasuraman, A and Grewal, D (2000), "The impact of technology on the quality-value-loyalty chain: a research agenda" Journal of the Academy of Marketing Science, Vol 28 No 1, pp 168-174.

Peppers, D., and Rogers, M. (1993) The One to One Future: Building Relationships One Customer at a Time, New York: Currency/Doubleday Peppers, D., and Rogers, M. (2004) Managing Customer Relationships, Hoboken, N.J.: Wiley

Price, L, Arnould, E, and Tierney, P (1995), "Going to extremes: managing service encounters and assessing provider performance", Journal of Marketing, Vol 59 No 2, pp 83-97

Price, L. and Arnould, E. (1999) Commercial Friendships: Service Provider-Client Relationships in Context. Journal of Marketing. Vol. 63 No. 4, pp. 38-56.

Reichheld, F.; Teal T. (1996), "The Loyalty Effect: The Hidden Force Behind Growth, Profits, and Lasting Value", Harvard Business Press, Cambridge.

Rowley, J.; Dawes, J. (2000), "Disloyalty: a closer look at non-loyals", Journal of Consumer Marketing, Vol 17 No 6, pp.538-549.

Rust, R., Zeithaml V., Lemon, K. (2000), Driving customer equity: how customer lifetime value is reshaping corporate strategy, The Free Press, New York.

Rust, R.; Oliver, R. (2000), "Should we delight the customer?", Journal of the Academy of Marketing Science, Vol 28 No 1, pp. 86-94.

Rust, R.; Lemon, K.; Zeithaml, V. (2001), "What drives customer equity”, Journal of Marketing Management, Vol 10 No 1, pp. 20-25.

Ryan, M.; Rayner, R.; Morrison, A. (1999), "Diagnosing customer loyalty drivers”, Journal of Marketing Research, Vol 11 No 2, pp. 18-26.

Singh, J.; Sirdeshmurk D. (2000), “Agency and trust mechanisms in customer satisfaction and loyalty judgements", Journal of the Academy of Marketing Science, Vol 28 No 1, pp. 150-167.

Singh, J.; Sirdeshmurk, D.; Sabol, B. (2002), "Consumer trust, value and loyalty in relational exchanges", Journal of Marketing, Vol 66 No 1, pp. 15-37.

Strauss, B.; Neuhaus P. (1997), “The Qualitative Satisfaction Model”, International Journal of Services Industry Management, Vol 9 No 2, pp.169-88

Tian, K., Bearden, W. and Hunter, G. (2001) Consumers' Need for Uniqueness: Scale Development and Validation. Journal of Consumer Research, Vol. 28 No. 2, pp. 50-66.

Tenenhaus, M. (1999), “L’ Approche PLS”, Revue Statistique Appliquée, Vol XLVII No 2, pp. 5-40.

Vilares, M.; Coelho, P. (2001), Relatório Metodológico: ECSI-Portugal, IPQ, Portugal.

Vilares, M.; Coelho, P. (2004), “The Employee-Customer Satisfaction Chain in the ECSI Model.”, European Journal of Marketing, vol. 37, 1703-1722.

Williams, O. F; Murphy, P. (1990), “The Ethics of Virtue: A Moral Theory for Marketing,” Journal of Macromarketing, vol. 10 (Spring), 19-29. 
Wilson, D. T. (1995), “An integrated model of buyer-seller relationships” Journal of the Academy of Marketing Science, Vol 23 No 4, pp. 335-345.

Zeithaml, V. (2000), "Service quality, profitability and the economic worth of customers: what we know and what we need to learn", Journal of the Academy of Marketing Science, Vol 28 No 1, pp. 6785.

Zeithaml, V.; Rust R.; Lemon K. (2001), "The Customer Pyramaid: Creating and Serving Profitable Customers." California Management Review, Vol 43 No 4, pp.118-142. 
Figure 1. The base model from Ball, Coelho, and Machás (2004)

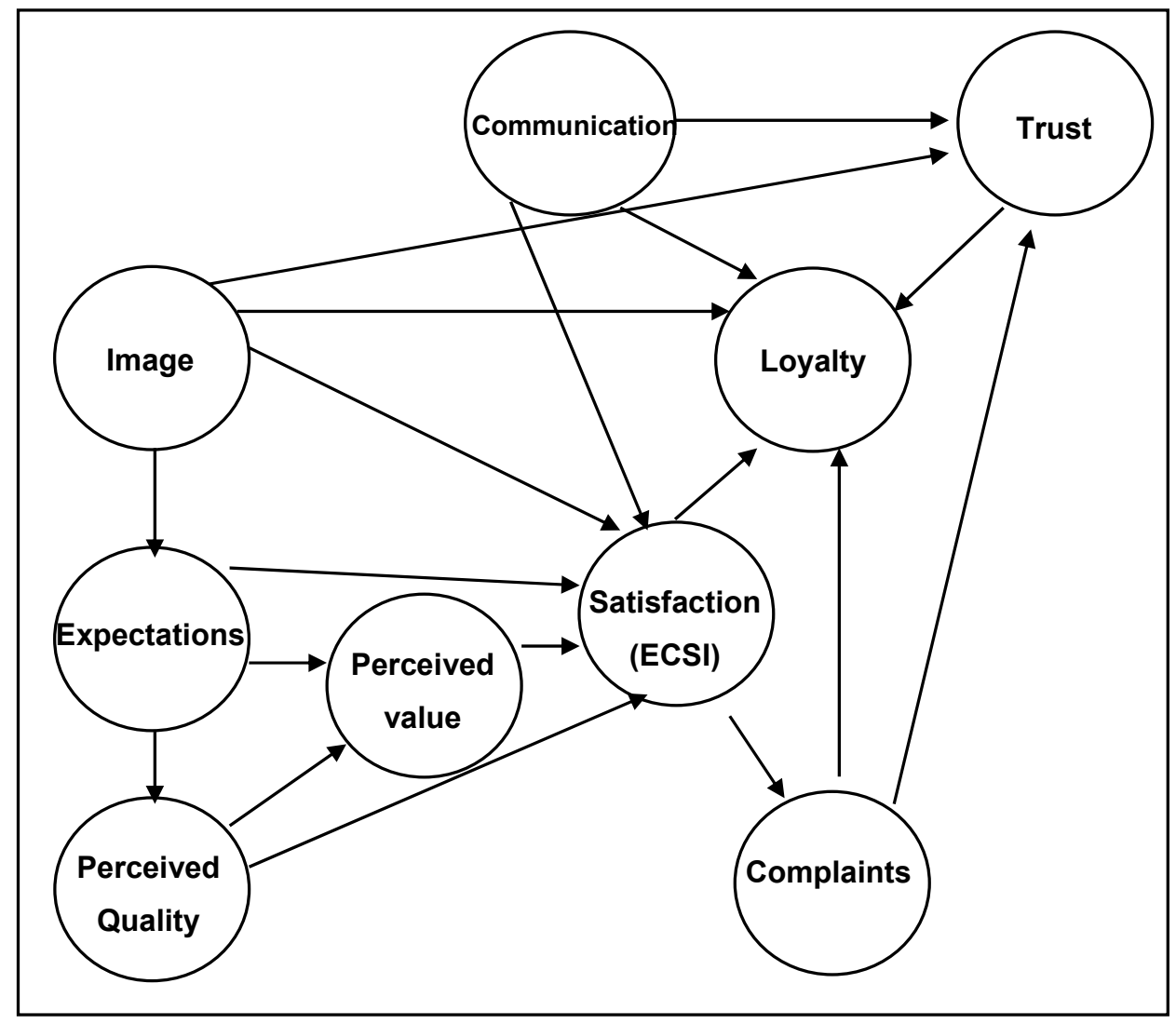


Figure 2. Model parameter estimates and $t$ values in the base model

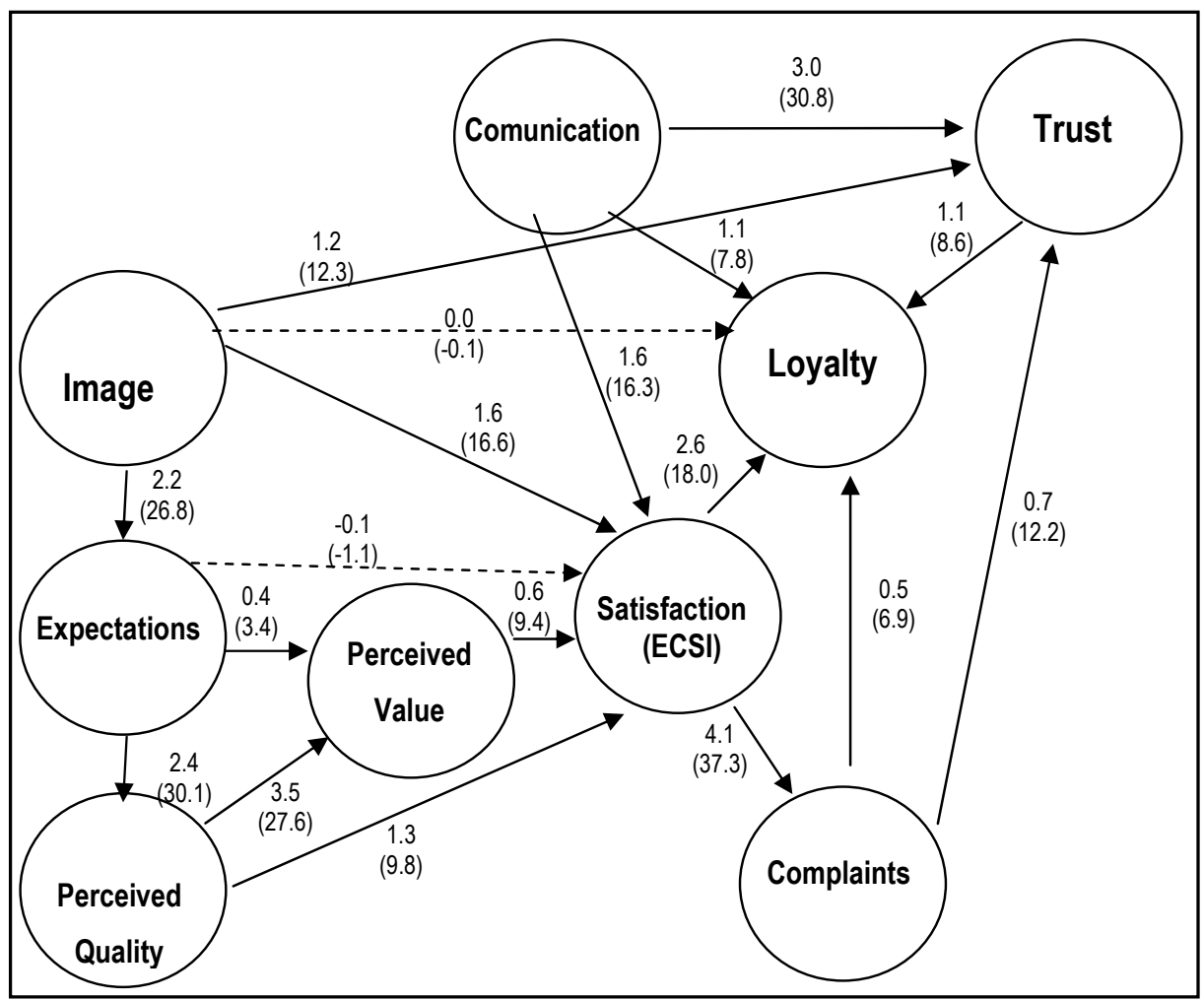


Figure 3. Revised Conceptual Model

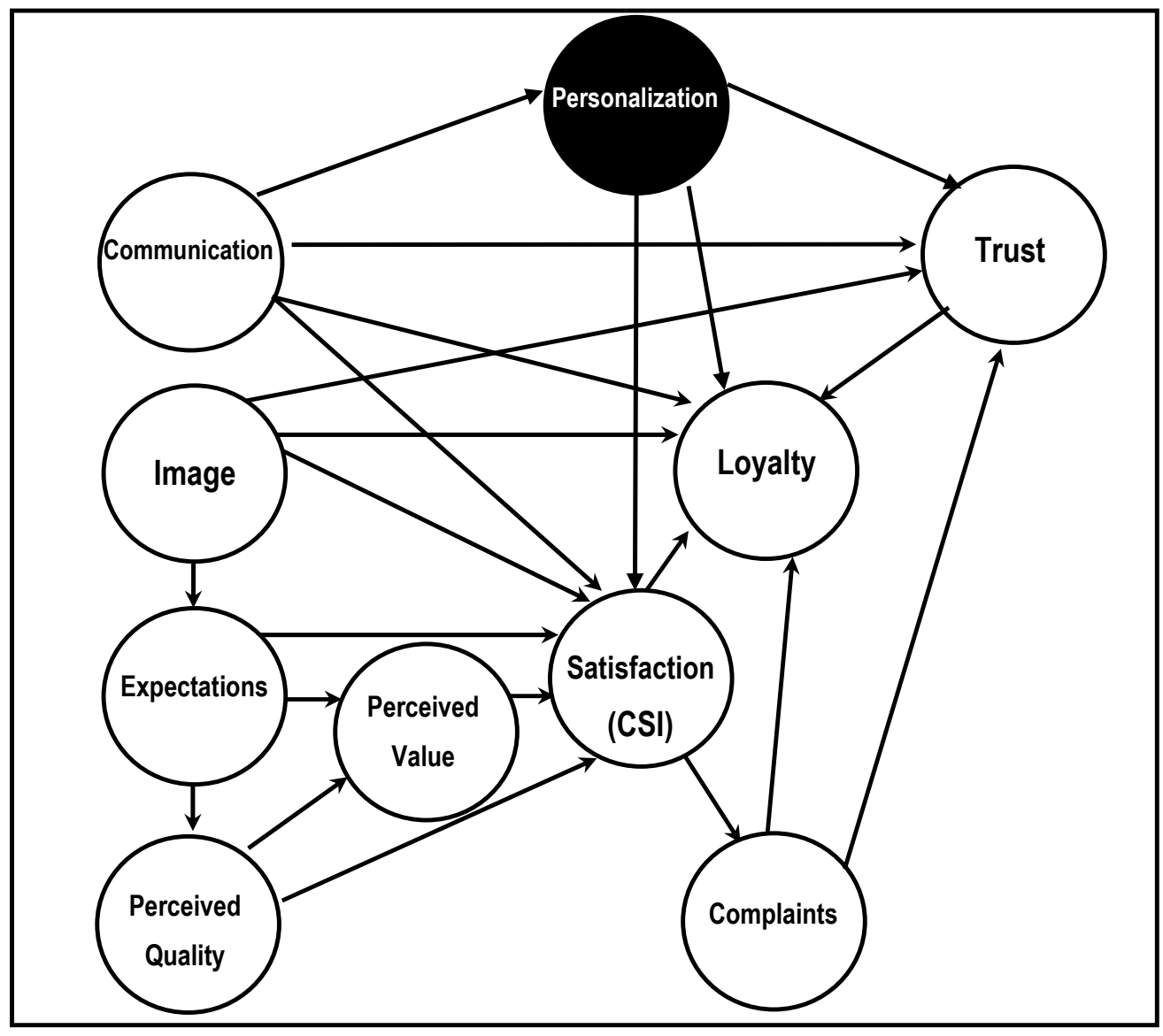


Figure 4. Model parameter estimates and $t$ values in the revised model

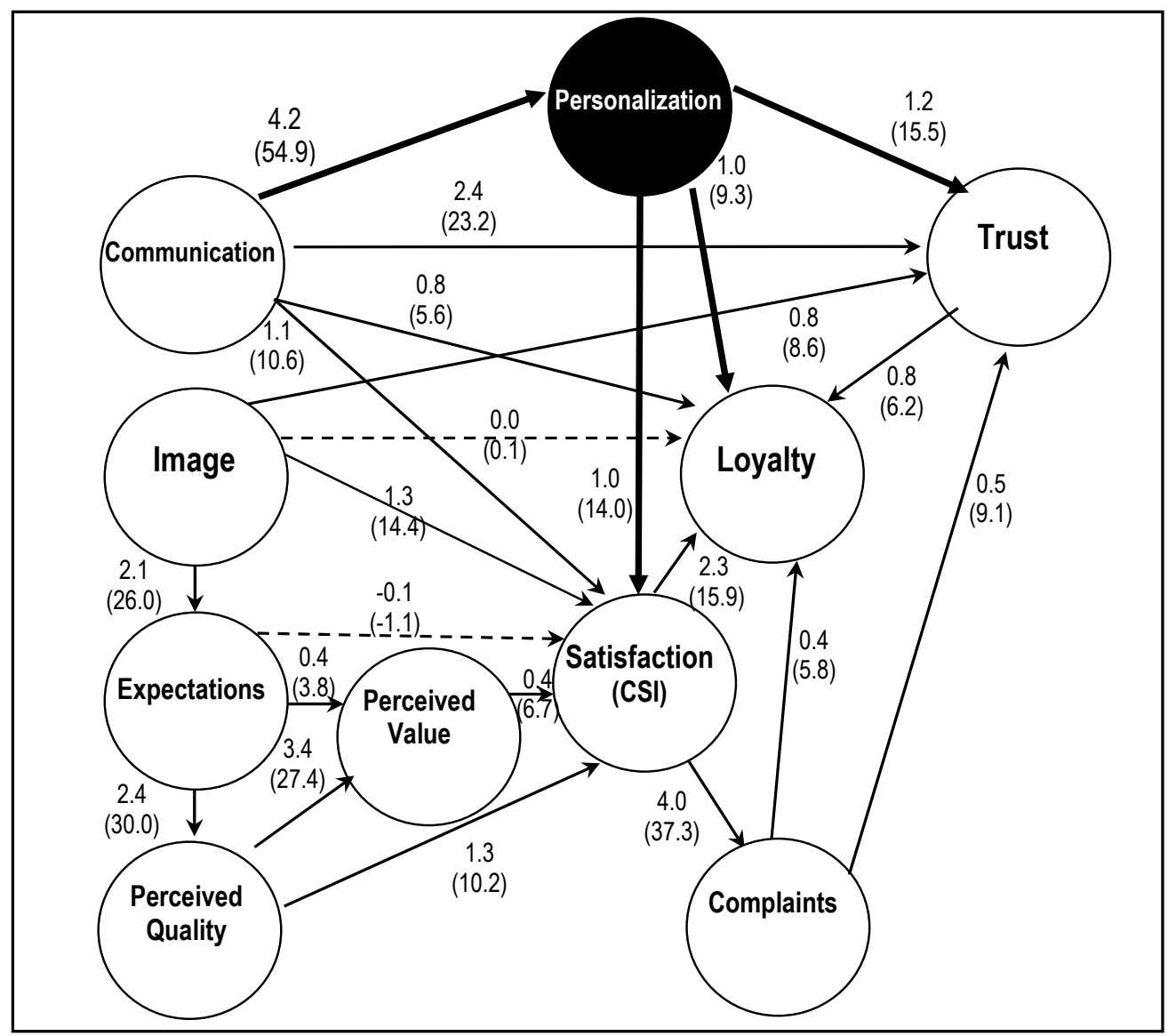


Table I. Indicators of communication, trust and personalization

\begin{tabular}{|c|c|}
\hline Latent Variable & Indicators \\
\hline Communication & $\begin{array}{l}x_{21}: \text { "The bank" establishes an easy and satisfactory relationship with } \\
\text { me (totally disagree to totally agree) } \\
x_{22}: \text { "The bank" keeps me constantly informed of new products and } \\
\text { services that could be in my interest (totally disagree to totally agree) } \\
x_{23}: \text { Level of advice provided by "my bank" (very poor to very good) } \\
x_{24}: \text { Clearness and transparency of information provided by "my } \\
\text { bank" (very poor to very good) }\end{array}$ \\
\hline Personalization & $\begin{array}{l}y_{41}: \text { "My bank" offers me products and services that satisfy my } \\
\text { specific needs } \\
y_{42}: \text { "My bank" offers products and services that I couldn't find in } \\
\text { another bank } \\
y_{43} \text { : If I changed from banks I wouldn't obtain products and services } \\
\text { as personalized as I have now }\end{array}$ \\
\hline Trust & $\begin{array}{l}y_{51}: \text { Overall, I have complete trust in "my bank" (totally disagree to } \\
\text { totally agree) } \\
y_{52}: \text { When "my bank" suggests that I buy a new product it is because } \\
\text { it is best for my situation (totally disagree to totally agree) } \\
y_{53}: \text { "My bank" treats me in an honest way in every transaction } \\
\text { (totally disagree to totally agree) }\end{array}$ \\
\hline
\end{tabular}


Table II. Determination coefficient $\left(R^{2}\right)$ of Satisfaction, Loyalty, Personalization and Trust

\begin{tabular}{|c|c|c|c|c|c|c|c|c|c|c|}
\hline \multirow{2}{*}{$\begin{array}{c}\text { Banks and } \\
\text { Sector } \\
\end{array}$} & \multicolumn{3}{|c|}{ Base Model } & \multicolumn{7}{|c|}{ Revised model } \\
\hline & Satisfaction & Loyalty & Trust & Satisfaction & Loyalty & Trust & Personalization & Dif.Sat. & Dif.Loyal. & Dif. Trust \\
\hline Bank 1 & 71.0 & 71.1 & 65.6 & 73.1 & 70.9 & 66.7 & 58.2 & 2.1 & -0.2 & 1.1 \\
\hline Bank 2 & 75.3 & 65.5 & 72.8 & 75.2 & 68.7 & 73.6 & 52.7 & -0.1 & 3.2 & 0.8 \\
\hline Bank 3 & 67.2 & 50.4 & 59.3 & 71.1 & 50.8 & 64.6 & 56.2 & 3.9 & 0.4 & 5.3 \\
\hline Bank 4 & 72.1 & 60.3 & 70.8 & 74.1 & 63.0 & 74.1 & 59.8 & 2.0 & 2.7 & 3.3 \\
\hline Bank 5 & 71.8 & 53.3 & 73.8 & 72.9 & 56.6 & 74.5 & 60.2 & 1.1 & 3.3 & 0.7 \\
\hline Bank 6 & 67.6 & 63.3 & 62.1 & 68.6 & 63.5 & 65.4 & 44.6 & 1.0 & 0.2 & 3.3 \\
\hline Bank 7 & 70.2 & 64.1 & 73.1 & 71.7 & 64.7 & 74.1 & 53.8 & 1.5 & 0.6 & 1.0 \\
\hline Bank 8 & 71.9 & 71.4 & 71.4 & 77.8 & 72.7 & 75.4 & 51.9 & 5.9 & 1.3 & 4.0 \\
\hline Bank 9 & 75.1 & 68.4 & 69.4 & 75.3 & 68.8 & 69.1 & 58.4 & 0.2 & 0.4 & -0.3 \\
\hline Bank 10 & 72.6 & 67.5 & 69.3 & 74.4 & 68.4 & 72.9 & 48.2 & 1.8 & 0.9 & 3.6 \\
\hline $\begin{array}{c}\text { Average } \\
\text { Banking sector } \\
\end{array}$ & 71.5 & 63.5 & 68.8 & 73.4 & 64.8 & 71.0 & 54.4 & 1.9 & 1.3 & 2.2 \\
\hline
\end{tabular}


Table III. Effect size $(f)$ for satisfaction, loyalty and trust

\begin{tabular}{|l|c|c|c|}
\hline & Satisfaction & Loyalty & Trust \\
\hline Image & 0.32 & 0.00 & 0.20 \\
\hline Expectations & 0.06 & - & - \\
\hline Quality & 0.19 & - & - \\
\hline Value & 0.15 & - & - \\
\hline Complaints & - & 0.13 & 0.20 \\
\hline Communication & 0.18 & 0.13 & 0.45 \\
\hline Personalization & 0.29 & 0.16 & 0.31 \\
\hline Trust & - & 0.12 & - \\
\hline Satisfaction & - & 0.34 & - \\
\hline
\end{tabular}

Table IV. Cronbach alpha, Communality and Redundancy by bank

\begin{tabular}{|c|c|c|c|}
\hline \multirow{2}{*}{ Banks and sector } & \multicolumn{3}{|c|}{ Personalization } \\
\cline { 2 - 4 } & Alpha & Communality & Redundancy \\
\hline Bank 1 & .839 & .758 & .441 \\
\hline Bank 2 & .806 & .724 & .382 \\
\hline Bank 3 & .821 & .740 & .416 \\
\hline Bank 4 & .825 & .740 & .443 \\
\hline Bank 5 & .804 & .718 & .432 \\
\hline Bank 6 & .813 & .730 & .325 \\
\hline Bank 7 & .835 & .755 & .406 \\
\hline Bank 8 & .846 & .765 & .397 \\
\hline Bank 9 & .791 & .706 & .412 \\
\hline Bank 10 & .808 & .723 & .348 \\
\hline $\begin{array}{c}\text { Average Banking } \\
\text { sector }\end{array}$ & $\mathbf{. 8 1 9}$ & .736 &. $\mathbf{4 0 0}$ \\
\hline
\end{tabular}


Table V. Percentage of latent variable squared correlations exceeding measurement variables communalities

\begin{tabular}{|c|c|c|c|c|}
\hline \multirow[t]{2}{*}{ Construct } & \multicolumn{2}{|c|}{$\begin{array}{c}\text { Latent variable squared } \\
\text { correlations exceeding } \\
\text { measurement variables' } \\
\text { communalities }\end{array}$} & \multicolumn{2}{|c|}{$\begin{array}{l}\text { Correlations with other latent } \\
\text { variables exceeding the } \\
\text { correlation with the directly } \\
\text { connected latent variable }\end{array}$} \\
\hline & $\begin{array}{c}\text { number of } \\
\text { comparisons }\end{array}$ & $\begin{array}{c}\% \text { of } \\
\text { violations } \\
\end{array}$ & $\begin{array}{c}\text { number of } \\
\text { comparisons }\end{array}$ & $\begin{array}{c}\% \% \text { of } \\
\text { violations } \\
\end{array}$ \\
\hline $\begin{array}{l}y_{41}: \text { "My bank" offers me } \\
\text { products and services that } \\
\text { satisfy my specific needs }\end{array}$ & 90 & $0.0 \%$ & 90 & $1.1 \%$ \\
\hline $\begin{array}{l}y_{42}: \text { "My bank" offers } \\
\text { products and services that I } \\
\text { couldn't find in another bank }\end{array}$ & 90 & $0.0 \%$ & 90 & $0.0 \%$ \\
\hline $\begin{array}{l}y_{43} \text { : If I changed from banks } \\
\text { I wouldn't obtain products } \\
\text { and services as personalized } \\
\text { as I have now }\end{array}$ & 90 & $0.0 \%$ & 90 & $0.0 \%$ \\
\hline Total & 270 & $0.0 \%$ & 270 & $0.4 \%$ \\
\hline
\end{tabular}

Table VI. Total impact on the base model

\begin{tabular}{|l|c|c|c|c|c|c|c|}
\hline \multicolumn{1}{|c|}{$\begin{array}{c}\text { Latent } \\
\text { Variables }\end{array}$} & Expectations & Quality & Value & Satisfaction & Complaints & Trust & Loyalty \\
\hline Image & 2.2 & 1.1 & 0.9 & 2.0 & 1.6 & 1.4 & 1.8 \\
\hline Expectations & & 2.4 & 2.1 & 0.8 & 0.7 & 0.1 & 0.5 \\
\hline Quality & & & 3.5 & 1.7 & 1.4 & 0.2 & 1.1 \\
\hline Value & & & & 0.6 & 0.5 & 0.1 & 0.4 \\
\hline Communication & & & & 1.6 & 1.3 & 3.1 & 2.7 \\
\hline Satisfaction & & & & & 4.1 & 0.5 & 3.1 \\
\hline Complaints & & & & & & 0.7 & 0.6 \\
\hline Trust & & & & & & & 1.1 \\
\hline
\end{tabular}


Table VII. Total impact on the revised model

\begin{tabular}{|l|c|c|c|c|c|c|c|c|}
\hline \multicolumn{1}{|c|}{$\begin{array}{c}\text { Latent } \\
\text { Variables }\end{array}$} & Expectations & Quality & Value & Personalization & Satisfaction & Complaints & Trust & Loyalty \\
\hline Image & 2.1 & 1.0 & 0.9 & & 0.3 & 0.3 & 0.8 & 0.3 \\
\hline Expectations & & 2.4 & 2.1 & & 0.8 & 0.6 & 0.1 & 0.4 \\
\hline Quality & & & 3.4 & & 1.6 & 1.3 & 0.1 & 0.8 \\
\hline Value & & & & & 0.4 & 0.3 & 0.0 & 0.2 \\
\hline Communication & & & & 4.2 & 1.9 & 1.6 & 3.5 & 3.2 \\
\hline Personalization & & & & & 1.0 & 0.8 & 1.3 & 1.7 \\
\hline Satisfaction & & & & & & 4.0 & 0.4 & 2.6 \\
\hline Complaints & & & & & & & 0.5 & 0.5 \\
\hline Trust & & & & & & & & 0.8 \\
\hline
\end{tabular}

${ }^{1}$ The sampling design is based on the random selection of households using RDD (random digit dialling). In each household the selection of a resident is also made randomly. The first set of questions in the questionnaire is used to qualify the potential respondent as a customer of the sector (banking) and of a particular bank. All the other questions in the questionnaire refer to the identified bank.

${ }^{2}$ These are the constructs not included in the standard ECSI-Portugal model. More detailed information about the questionnaire and the indicators use to measure the standard constructs can be found in Vilares and Coelho (2001).

${ }^{3}$ It should be stated that the gains in explanatory power are relatively modest and that the nature of $R^{2}$ is such that the inclusion of a new explanatory construct will always increase its value. One alternative would be to use the adjusted $R^{2}$ that takes into account the model complexity. Nevertheless, since the number of observations is relatively large ( 250 per brand), the adjusted $R^{2}$ are numerically very similar to the unadjusted ones and also show improvements in the revised model.

${ }^{4}$ Effect size measures the relevance of each predictor of a dependent latent variable and is based on the relationship of determination coefficients when including or excluding a particular predictor from the structural equation.

${ }^{5}$ Communality for a manifest variable may be interpreted as the proportion of its variance, which is reproduced by the directly connected latent variable. The redundancy coefficient for a manifest variable is the proportion of its variance, which is reproduced by the predictors of its own latent variable. Communalities and redundancy coefficients for latent variables are averages of the communalities and redundancy of their manifests. 